\title{
Eco Product Innovation in Search of Meaning: Incremental and Radical Practice for Sustainability Development
}

\author{
Lizwa Rashid $^{1}$, Salleh Yahya ${ }^{1}$, Samer Ali Shamee ${ }^{1}$, Juhaini Jabar ${ }^{1}$, Muliati Sedek ${ }^{1} \&$ Sarah Halim $^{1}$ \\ ${ }^{1}$ Faculty of Technology Management \& Technopreneurship, Universiti Teknikal Malaysia Melaka, Malaysia \\ Correspondence: Lizwa Rashid, Faculty of Technology Management \& Technopreneurship, Universiti Teknikal \\ Malaysia Melaka, Malaysia. E-mail: nlizwa84@yahoo.com
}

$\begin{array}{lc}\text { Received: March 15, } 2014 & \text { Accepted: April 24, } 2014 \quad \text { Online Published: June 25, } 2014 \\ \text { doi:10.5539/ass.v10n13p78 } & \text { URL: http://dx.doi.org/10.5539/ass.v10n13p78 }\end{array}$

\begin{abstract}
Purpose: The purpose of this paper is to discuss the role of eco innovation in order to achieve sustainable development in manufacturing industries. The outcomes of this paper attempts to describe the main drivers of eco innovation among companies, core categories of eco innovation practices in manufacturing industry and framework of radical and incremental eco product innovation. The last part of the paper provides the insight of the new paradigm for eco innovation research in new millennium particularly in developing countries.
\end{abstract}

Design/methodology/Approach: The selected papers that have been reviewed were retrieved from Google scholar database with high citation index.

Findings: Manufacturing acknowledges eco innovation as a pivotal role to attain sustainability development in ecology, economy and society. There are three main drivers that able to boost the manufacturing sustainability namely regulation, responsibility and competition. Four types of eco innovation practices are product, process, marketing and organizations. However, among of them, eco product innovation is highly discussed among scholars in new millennium. Most of high cited literature describes the dimension of radical and incremental literature in four dimensions: modes of changes, economy values, design changes and eco innovation practices. The new research paradigm should discuss on eco innovation management in manufacturing industry.

Originality/value: Most of scholars are confused with the correct concept of eco innovation and its relationship towards sustainability development. Therefore, this paper attempts to provide a clear direction on difference between the incremental and radical eco product innovation implementation in manufacturing industry en route for building the sustainable development echoes to economy, ecology and society.

Keywords: Eco product innovation, radical and incremental, sustainability development

\section{Introduction}

Manufacturing recognized as a core business for many companies and plays a significant role for economic and social development. In the early 1980, manufacturing competition lies on the practice of improving production efficiency in terms of quality, cost and time. Common manufacturing practice as Total quality management

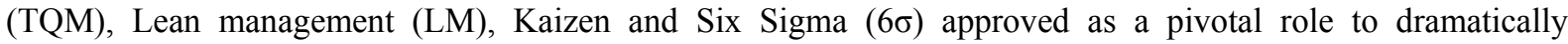
improved production efficiency, but insignificant used as a weapon for the sustainable competitive advantage (Hayes, Pisano, Upton, \& Wheelwright, 2005). Therefore, in order to sustain, companies are required to be a frontier in their activities (Porter, 1991) and provide a superior and unique product to maintain market positioning (Cooper \& Edgett, 2006). Thus, innovation is crucial as a driving engine in sustaining both the economic growth and nation development (Soliman, 2013; Bogliacino, Perani, Pianta, \& Supino, 2012; Revilla Diez, \& Kiese, 2006).

Furthermore, in new millennium, due to rapid changing of customer demand and national regulation, companies acknowledge an innovation in the form of environmental technology as the heart of the competitive advantage (Rennings, 2000). Most manufacturers believe by implementing environmental activities, effect on the company profit as incur in cost of operation in waste treatment and management. Limited companies involved in integrating environmental practices in manufacturing process or developing a green product because of the unstable demand and high investment to explore new technology. Recently, more studies conducted in profiling eco innovation dimension, implementation, driver and barriers. Most of the extensive research in the innovation 
studies has been conducted by the Organization of Economic Cooperation Development (OECD). The eco innovation practice as reported by OECD manual ranged from the introduction of new product, process, method and organization (Manufacturing, 2009). Therefore, this paper provides an insight on several questions embedded between the literature and manufacturer in attempts to justify the dimension and benefits of effective implementation of environmental practice in the manufacturing industry. This paper provides a meaningful review to clarify several questions listed as below:

a) What are the drivers of sustainability building between the global manufacturing industries?

b) What are the types of eco innovation practices implement in manufacturing activities?

c) What are the dimensions of radical and incremental eco product innovation towards sustainability development?

\section{Drivers of Sustainability Development}

As the environmental issues arose dramatically almost 50 decades, a Brundtland report 1987 and ECO 92 report in Brazil have shed a light on the environmental sustainability issues and accentuated an awareness among the NGOs, politician and business leader (Angelo, Jabbour, \& Galina, 2012; Dyllick \& Hockerts, 2002). The concept of sustainability development refers as 'the ability of current generation to meet their needs without compromising the ability of future generations to meet theirs'(WCED, 1987). The strong voice in both conferences has made tremendous changes in manufacturing perception in doing business. Manufacturing are driving to eco innovate based on three main factors; regulation, responsibility and competition (Dangelico \& Pujari, 2010; Rennings, 2000). Porter in his report strongly recommended that nation development should emphasize on environmental regulation because it will increase on the innovation activities and good economic exchange (Porter \& Linde, 1995; Porter, 1991). In Canada, the government has enforced the manufacturing process to innovate based on the environmental friendly technology. In Europe, eco innovation practices incorporate services sectors such as consulting services as one of the main factors to reduce environmental risk and increase economy exchange. In such, Japanese acknowledge eco innovation in a form of social development which integrated the environment and people to reduce environmental issues. As far as now, eco innovation implementation in the OECD countries, is not only central in government regulation, but has been wider to policies initiatives under the umbrella of supply side and demand side (Machiba, 2009). Supply side initiatives rest on the government programs to encourage eco innovation exploration through funding the eco project, encourage R\&D, education and training, creating a network and partnership. Similarly, at the demand side relies at the adoption and diffusion stages to the business activities, where government role on emphasizing the regulation of producing green product and increases the customer awareness to purchase eco product labelling scheme. Thus, through strong regulation from government to eco innovate between manufacturer and customer will regulate the awareness of sustainability development.

The second drivers of sustainability development depend on the responsibility of both top management and stakeholders. Manufacturing activities believe to be the major contributor for environmental pollution from the process of taking natural resources, making a product and producing waste and emission contributed on the $61 \%$ of world energy consumption and 36\% of global C02 emission respectively (Manufacturing, 2009). Continuing exploitation of natural resources resulted in increasing of Green House effect (GHG), natural disaster such as water, air and soil contamination and indirectly effect on the human health and social life. In $21^{\text {st }}$ century, the sustainable concept are accepted and adopted in a business strategy as the management mission. Companies are more responsible and aware on production activities especially generation of toxic waste and exploitation of natural resources. Therefore, environmental practice in manufacturing process is a reaction by top management which comply with the regulation in order to control the industry pollution namely; (i) Environmental management such as ISO 14001 audit series, (ii) Environmental regulation namely, restriction on Chlorofluorocarbon in product usage in 1987, C02 emission control in Kyoto Protocol, Restriction of Hazardous Substances (RoHS) in Electric and Electronic Equipment (iii) Environmental program such and Waste electronics and electrical equipment (WEEE) for collection end life electronic product. Furthermore, top management implies the environmental practices to improve their business model. Most of the environmental compliances related to the customer demands specifically in automotive industry. The automaker enforced their suppliers to increase the production efficiency through minimizing waste and energy used.

Lastly, the drivers of environmental implementation reflect on the competition strategy. A green practice at the firm's level at one hand reflects on the increasing of firm image and cost of operations through compliances towards environmental regulations. Indirectly they will nurture the environmental spirit to their customers by introducing a green product. Recently, demand on green product can be considered at early stage, but will grow 
dramatically in future (Halila \& Rundquist, 2011). Increasing awareness of green consumerism and introduction of eco friendly product represent that customers are willing to pay at premium price in attempt to protect the environment. Green product concept widely accepted by all kind of product from basic to luxury because of changes in customer purchasing behavior (Sharma, Sonwalkar, \& Maohr, 2013; Mei, Ling, \& Piew, 2012; Tsen, Phang, Hasan, \& Buncha, 2006). Borin and Lindsey-mullikin (2010) in analysis of purchase intention between green and non green product discover that, customers are willing to buy a green product in form of new green, recycle or refurbish product and company who practice green manufacturing in production process. Designing a new product in the $21^{\text {st }}$ century shows tremendous challenge because the mission in doing business rely on sustainability performance in triple bottom line dimension; wealth creation, social development and pollution prevention (Dyllick \& Hockerts, 2002).

\section{Types of Eco Innovation Practices in Manufacturing Industry}

Eco innovation terminology refers as an ecological, environmental, green and sustainable innovation initiate in most previous publications (Angelo et al., 2012; Schiederig, Tietze, \& Herstatt, 2012) and the terms have resemblance in the objective to reduce the environmental impacts (Schiederig et al., 2012). Fussler and James (1996) was known as the pioneer in this field and they defined eco innovation as a creation of product, process and services which offers value creation and simultaneously reduced environmental effect. On the other hand, a mass findings from previous research since the late 1990s until the 21 st century have shown that, eco innovation is best described as innovations activities performed at every levels of society or community that related in reducing environmental risk, pollution, waste and resource used (Arundel \& Kemp, 2009; Machiba, 2009; Kemp \& Pearson, 2008; Rennings, 2000).Apart from it, manufacturing is accepted by many scholars as the heart of eco innovation practices towards building the sustainable society.

Manufacturing competitive advantage relies on producing innovative product. However, new trends of market embrace to the development of eco product compared to the product innovation because its contribution on lowering the environmental risk (Kemp \& Person, 2007; Machiba, 2009). Eco innovation management in manufacturing depends on the degree of organization evolution and perception either in the form of reactive, preventive or pro active. The reactive and preventive are central on company compliances towards regulation and market demand, while the pro actives companies are significant in exploring new market opportunities and as an effort to minimize environmental problem (Angelo et al., 2012). In summary, eco product innovation development incorporate on reducing or eliminating usage of harmful materials, waste, and pollution (Arundel \& Kemp, 2009; Ottman, Stafford, \& Hartman, 2006). Recently, manufacturing companies are aware on new trends and looking for the best practice to manage their manufacturing process to produce product in green manner.

As reported in the (Manufacturing, 2009) eco-innovation practices outline its target or object (products, processes, marketing methods, organizational and institutions) as indicated in table 1; which contrary in report by Rennings (2000), eco target includes product, process, organizational, social and institutional. Meanwhile Arundel and Kemp (2009) defines eco target falls as the four categories such as environmental technologies, organizational innovation, product and service innovation and green system innovation. Broad definition of eco innovation can be found in Carrillo-Hermosilla, del Río, and Könnölä (2010), yet, eco innovation definition in OECD manual is a pertinent to organization as useful guidelines (Arundel \& Kemp, 2009), because the innovation definition acceptance worldwide and the innovation information ahead compared to others institution. OECD report in eco innovation in industry promoted that eco innovation typology rest on target; technical (product and process) and non technical (marketing, organizational and institution) innovation, mechanism or methods of changes (modification, redesign, alternatives and creation); and level of environmental impact (product life cycle). The definition of eco innovation target describe as below:

Eco product innovation related on the designing product that is not harmed to the environment during either in the development process by minimizing the used of material, energy, resources or the product disposal is less polluted. The implementing of eco process innovation associated on the changing of production methods to be efficient in managing the flow of material input to output. Meanwhile, the organizational innovation is embedded to managerial level intention on controlling the impact of pollution via changes in companies' policy and auditing systems. In the institutional innovation initiatives, involves in both formal and informal approach. In one hand, formal change related to the companies openness in public to incorporate the environmental rules and regulations, while in non formal approach, related to the transformation of culture in organization or society to be tolerate to environmental concern. However, the broad concept of eco target only gives a rudimentary indication to differentiate the eco innovation practices. In line with this statement (Rogers E.M (2003) in his book diffusion of innovation, he argued that the distinction between product and process is not clear when a new product becomes a part of process in another location in the value chain. On top of that, Hellström, (2007) and 
Rennings, (2000) defined product and process as one entity by means of integrated environmental technology when the companies implementing both types of innovation to generate product that less harmful to environment.

Table 1. Eco innovation target and description

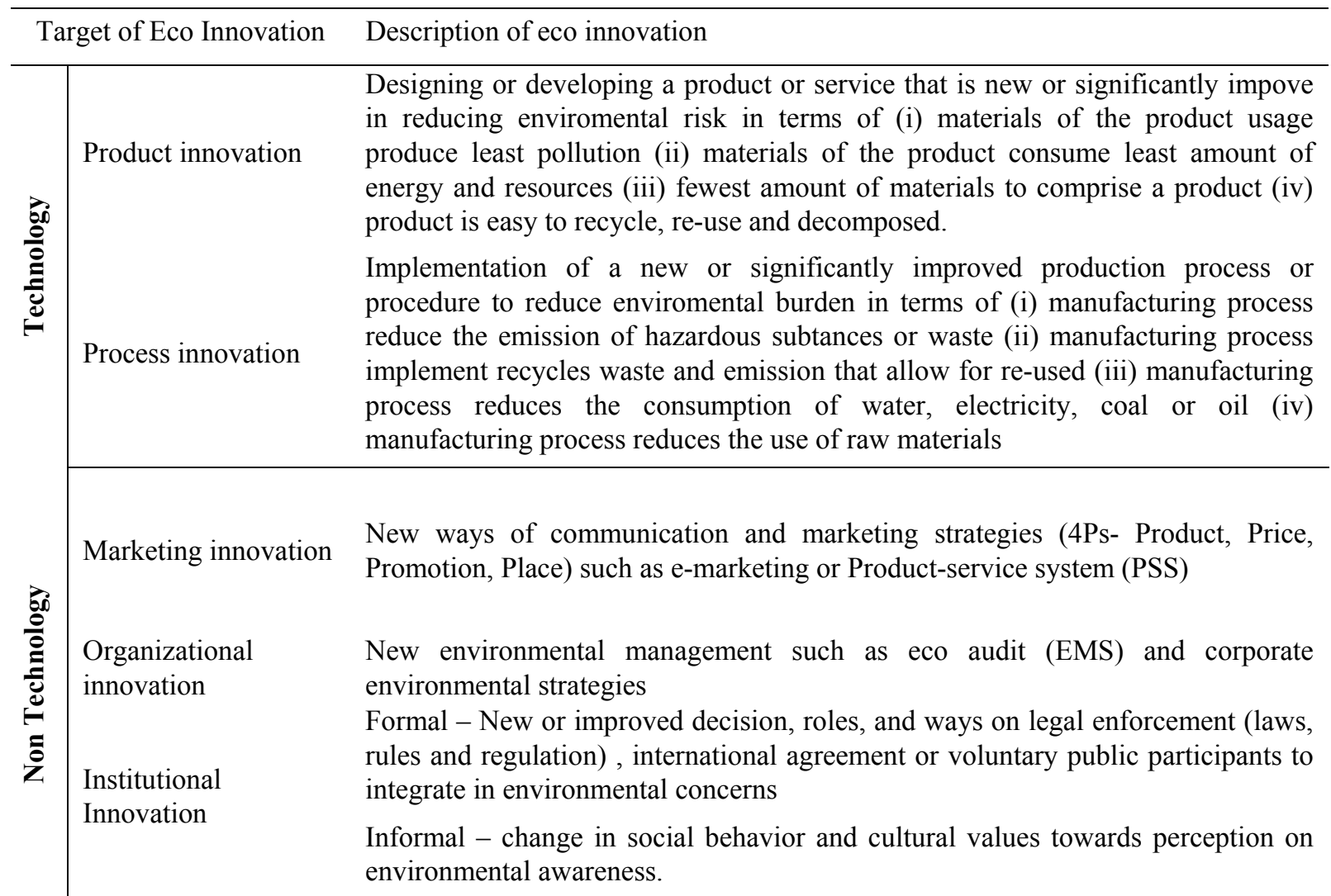

Adapted from: (Machiba, 2009; Manufacturing, 2009; Chen, Lai, \& Wen, 2006; Rennings, 2000)

The aforementioned findings, linkage on the eco innovation definition and new product development, echo the establishment of green product innovation framework by (Dangelico \& Pujari, 2010). The development of green product innovation or new green product occupied in three key types of environmental focus which is material, energy and pollution while its impacts occurred in different stages of product life cycle (PLC) including manufacturing process, product use and disposal as describe in figure 1: In the manufacturing process, the utilization of resource in material and energy required in terms of recycle, recyclable and biodegradable material or packaging usage in process development. In sync, energy efficiency is requisite during the production process by implementing or use of renewable energy source in manufacturing process. In the product use, eco product will reduce the usage of energy or product operates by using the renewable energy sources. In the pollution focus, firm implement cleaner pollution technology to reduce the pollution in the production process or the product generate is less or no effects to the environment. In sum, Devashish Pujari as one of the pioneer in green product study, defines eco product innovation as a developing of product with low input of material and energy to produce less pollution along the product life cycles (PLC) either in the manufacturing process, product usage or disposal stage (Dangelico \& Pujari, 2010) 


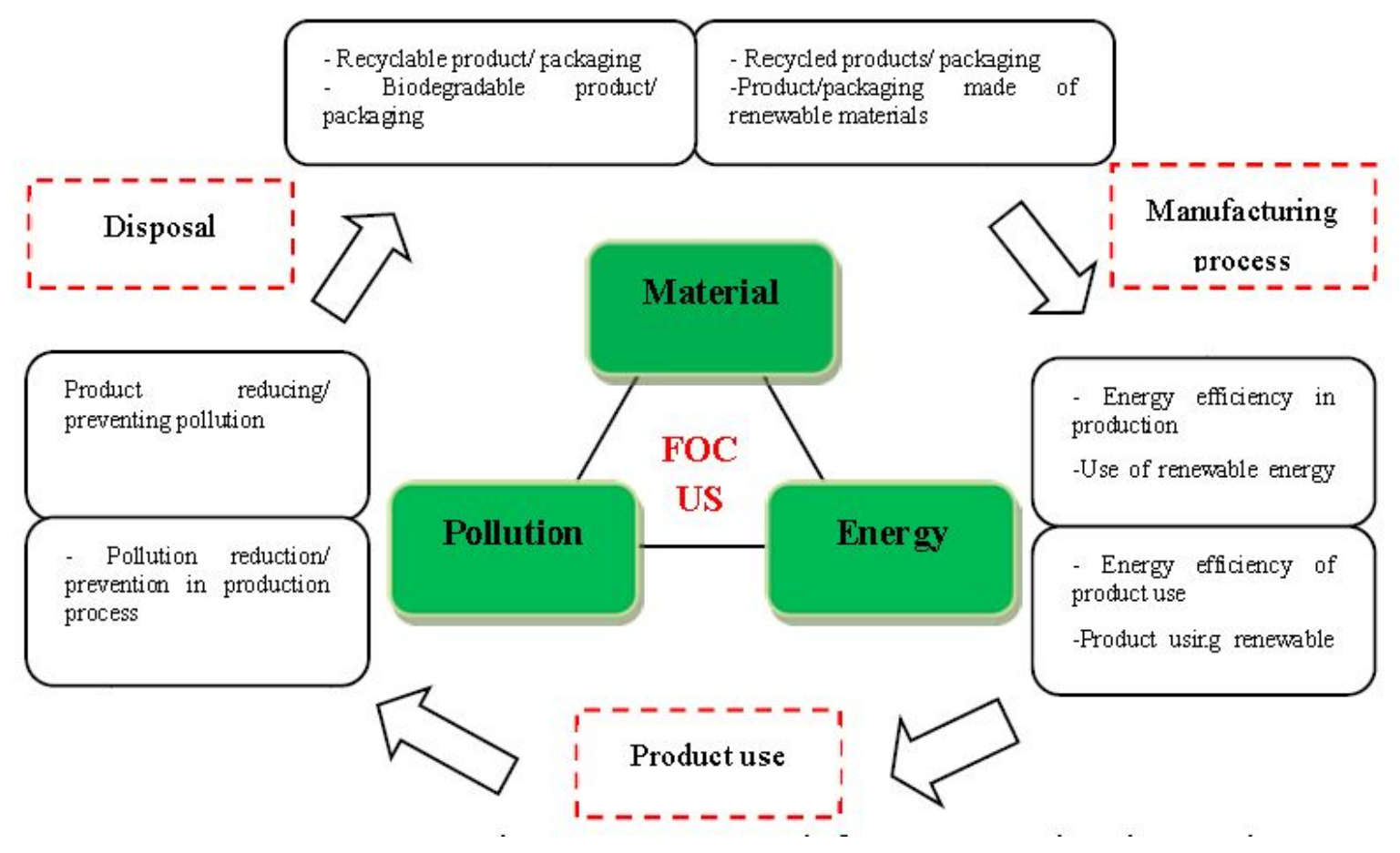

Figure 1. Framework for green product innovation

\section{Dimension of Incremental and Radical Innovation}

More authors have explained and explored about radical- incremental incident in eco innovation typology in differences views (Brezet, 1997; Carrillo-Hermosilla et al., 2010; Dangelico \& Pujari, 2010; Hellström, 2007; OECD, 2005, 2012).Mass findings provide insight to different the innovation strategy as below:

a) Modes of changes: Soft and hard elements.

b) Economy values: value added or value creation

c) Design changes: Component or architectural changes

d) Eco innovation practices towards sustainability development

An incremental green product innovation is referring to the minor improvement of previous product versions using existing or low technologies and skill of employees. Changes performing based on value added activity to continuously improve product or process performance and respond based on customer demand. This type of innovation is straightforward as changes are based on the similar production and network while no marketing research evaluate a new needs of customer. On the other side, radical innovation required the transformation on soft elements such as social and skill while hard elements in terms of high technology and machinery (Hellström, 2007). The activities defines as a destructive activities because requisite to conduct research and development (R\&D) in new marketing, technology, operation and management respectively. The activities renown as value creation in economist as the output of the activities creates a new system. Companies applying patent to guarantee product copyright as they have a right as a pioneer for the product development (Dangelico \& Pujari, 2010). Both type of innovation brings different challenges to carry out as level of complexity increase from incremental to radical, however, performing radical innovation resulted on sustainability development in triple bottom line effect of social, economy and ecology.

There are several authors discussing on the changes in product design to differences the incremental and radical changes (Hellström, 2007; Halila \& Horte, 2006; Ehrenfeld, 2001; Brezet,1997). The most influences design change definition in eco innovation initiate by Brezet, J.C and it is widely discusses in literature (Halila, 2007). Brezet (1997), developed four types of eco design model which comprised of (i) product improvement, (ii) redesign product, (iii) function innovation and (iv) system innovation. The model is purely related to changes in product innovation which incremental defines as product made base on environmental compliances or added a substances with the attention to reduce the environmental impact in product life cycle. Radical innovation 
engaged on development of new product that functions as a replacement of the existing product or introducing a new product that changes the entire system of usage. Brezet,J.C model encourages Ehrenfeld (2001) to develop the eco innovation categories and level of changes dimensions. He agreed that eco innovation design changes can be both products and services which embedded in four types of category; process and product redesign (category 1), functional innovation (category 2), institutional innovation (category 3) and system innovation (category 4). The former categories reflect on the incremental innovation as the changes are minor or none in device concept, infrastructure and changes in users learning. The later categories rest on radical innovation as reflect on minor to significant changes in three categories (Smith, 2008). Halila and Horte (2006) in their research which extending Brezet,J.C model because they argued that product improvement, redesign product and function innovation are improperly described and uneasily understood. However, eco innovation model developed by Halila and Horte (2006) is a holistic in describing the changes of product innovation and are not specifically discussing the changes in eco product innovation. In summary, there are three most influence journal describing the radical incremental changes in eco innovation practices in Product life cycle are belong to (Carrillo-Hermosilla et al., 2010; Dangelico \& Pujari, 2010; Hellström, 2007). Devashish Pujari proposal in eco product innovation framework is highly cited while Hermosilla,J.C and Hellstrom,T model is widely acceptance in describing changes in radical incremental eco innovation practices.

Hellström (2007) as the founder of incremental-radical in eco innovation describes type of changes in both innovations can be either in form of component or architecture. A component change is related on the replacement of one element within a larger system while the architecture relate on changes in altering the overall system design and mode of connection within the system. Under the umbrella of eco innovation typology, pollution prevention and cleaner production, obviously lies on the incremental innovation because it is related on the minor improvement such as component addition and sub-system change (Carrillo-Hermosilla et al., 2010). Changes made in the production system or curative action has limited impact to the environment and most probably the impact is unknown. Pollution control or end of pipe technology is a classical approach related on the additional component or devices (scrubber, filter, catalytic converters) and waste treatment at the end of production process to control air and water quality. Even though this technology has impact to environment, however this technology seems to be as burden to the companies as the treatment require investment and reflect on diverging company profit and economy growth Porter \& Linde (1995) and the implementation based on regulatory push (Rennings, 2000). Other approach is the cleaner production which focusing on the preventive solution at the earlier stages in production lines to treat the source of pollution. (Machiba, 2009) reported four applicable approaches by companies in reducing environmental risk namely; (i) housekeeping in production process and work practice (ii) Process optimization and low toxic materials used (iii) new technologies (iv) new design. Greening the production is much cheaper than curative technology as the impact indirectly increased on the manufacturing efficiency (reduced defect, maximized quality),reduced cost of operations and non compliances punishment of effluent or emission (Arundel \& Kemp, 2009; Hart, Ahuja, \& Arbor, 1996)

The World Business Council for Sustainable Development (WBCSD) initiates the notion of eco efficiency in business level to leverage sustainable development with the objective is to "produce more goods or services with less waste and pollution". MEI measures companies performance in seven eco efficiency such as; energy, water and material consumption, Greenhouse gas, other gas emission and total waste output and total waste mass balance (Kemp \& Person, 2007). Companies are advised to monitor, audit and plan strategies for their production process which align the eco efficiency objective. Performing environmental management system (EMS) benefits the companies in designing their activities based on environmental thinking, increase corporate images and better economic performance. Life cycle thinking linked to the green supply chain methodology. Companies performing environmental assessment in every stage of product life cycles and measure suppliers' performance based on quality, cost, and delivery and environmental to ensure non hazardous product supplied. Further, product and packaging used back in the production line to reduce cost of operation.

Incremental eco product innovation related on replacement of conventional materials with recycles components, eco efficiency production and design for recyclable product. However, eco efficiency and life cycle thinking can be both incremental and radical changes depending on their impact to environmental. Radical eco product is much significant on replacement of critical components that resulted on high impact to environment, creation a valuable new product from recycle components or creation a new product that superior in technology and new to the market. Closed loop production, and industrial ecology lies on the radial innovation related on usage of alternative components and creation of new system that have a significant impact to reduce environmental burden. 
In the radical green product implementation, two alternative design followed; close loop and open loop production system. Close loop production promotes reuse, recovery and remanufacturer where companies collect an end used product from a customer, dissemble and process them into valuable new product or rebirth the end life product while maintaining the identity and functionality of the original product. In the industrial ecology or called the open loop design, are which the materials can be both recycled on industrial production system or biodegradable by the natural environment. The product is designed to be biodegradable and has zero risk impact to environment during disposal. Radical product innovation can also be referred to as the development a new product based on efficiency approach which react as substitute to the existing product but advance in technology, for examples the introduction of hybrid and hydrogen alternatives for energy efficient vehicles (EEV) in terms of lowering fuel consumption and carbon emission.

To conclude, the eco product innovation in manufacturing can be best understood as producing product that less pollutant to environment through efficient usage of material, energy and resource (incremental). In a radical change, the production process is known as complex because the environmental impact is higher. The implementation consist of developing a green product that behave as creation a superior product to eliminate the environmental pollution or using a substitute material such as recycle material or biodegradable components in product design. Figure 2 shows a holistic diagram level of eco innovation implementation between radical-incremental dimensions towards achieving sustainable development.

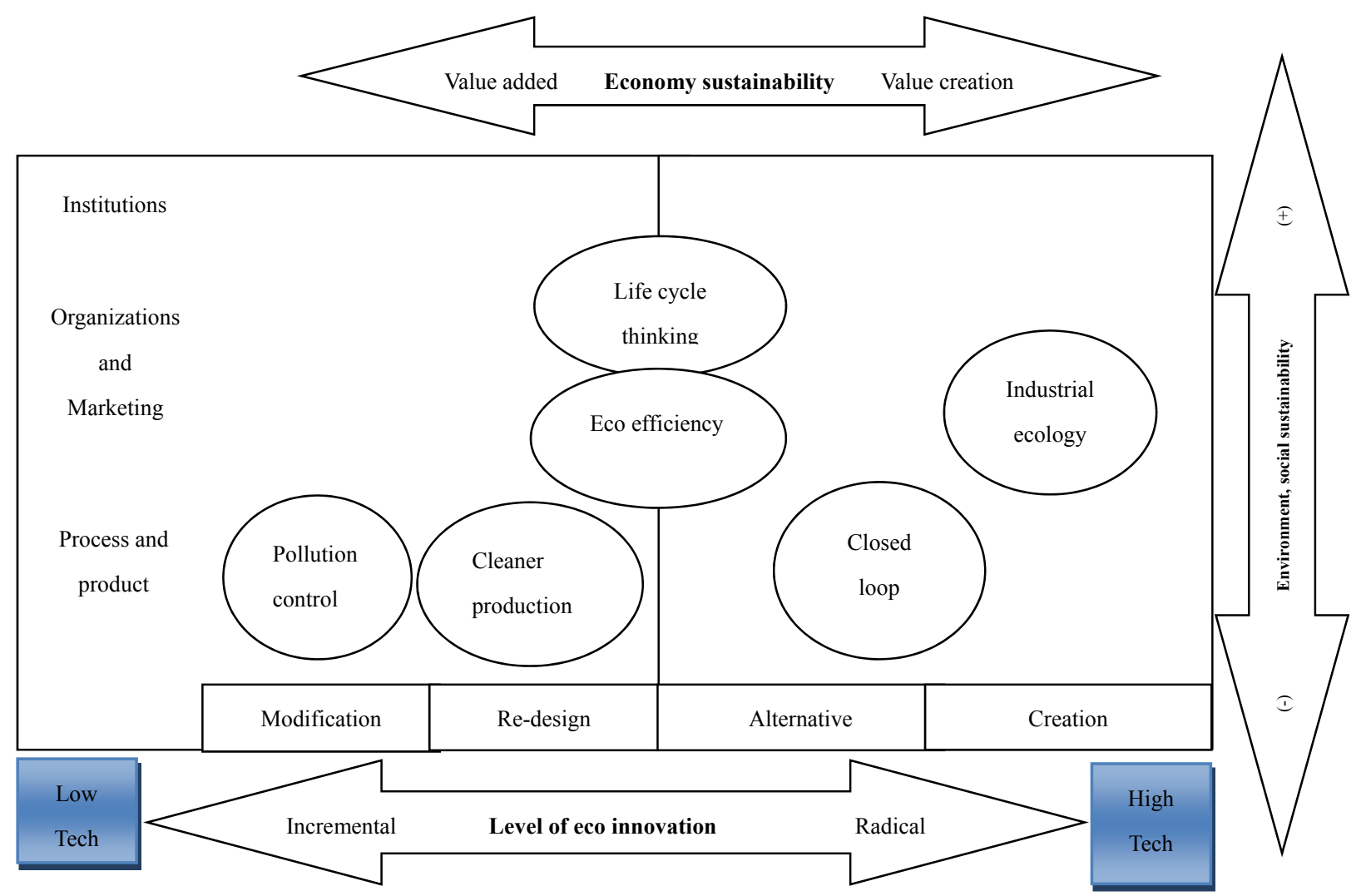

Figure 2. Conceptual diagram of radical-incremental eco innovation towards sustainability development adapted from (Carrillo-Hermosilla et al., 2010; Machiba, 2009;Hellström, 2007)

\section{Paradigm for Eco Innovation Research in New Millennium}

Eco innovation approved as a bridge to achieve sustainability (Kijek \& Kasztelan, 2013; Angelo et al., 2012; Carrillo-Hermosilla et al., 2010) and manufacturing industries are the perfect medium to achieve the mission (Sezen \& Çankaya, 2013). The growing attention of global concerned on sustainability and green practices acquire attention of both institutes and academic to discover the phenomenon. In one hand, more insight into best practices in manufacturing activities developed by OECD as guidance to leverage sustainability development (Machiba, 2009). Schiederig et al., (2012) reported that, a total of 8516 publications related to green, ecology, environment and sustainability domain released from 1990 to 2010 , which $62.6 \%$ of the scholar dominated in 
Business, administrations, finance and economics (BAFE) relatives to other fields. However, the central topics under the umbrella of eco innovation is unbalance as widen knowledge determine at macro level in marketing and economic research ( Rennings \& Rammer, 2010;Porter, 1991) compared to Meso and Micro level explicitly in green innovation management (Driessen, Hillebrand, Kok, \& Verhallen, 2013; Schiederig et al., 2012; Halila, 2007) and new product development (Dangelico \& Pujari, 2010; Pujari, 2006).

Although recent publication shows an increasing trends of literature found in eco innovation and new product development domain; (i) resource base view in corporate environmental performance (Hart, 1995; Russo \& Fouts, 1997) (ii) best practices of green product innovation activities (Pujari, 2006;Pujari, Peattie, \& Wright, 2004) (iii) dimension of eco innovation (Carrillo-Hermosilla et al., 2010; Dangelico \& Pujari, 2010; Hellström, 2007) (iv) market performance of green product (Halila \& Rundquist, 2011; Sharma et al., 2013) and (v) measurement of eco innovation (Arundel \& Kemp, 2009), however, academician and managers are keen to learn "how companies performing environmental innovation into manufacturing process particularly in developing a new product at the different level of innovation (radical versus incremental) and types of environmental focus (material driven, energy based or pollution prevention)" as limited knowledge and empirical study found in literature regarding on capabilities needed to manage green product innovation at Micro and Meso level specifically in developing countries (Schiederig et al., 2012; Carrillo-Hermosilla et al., 2010; Dangelico \& Pujari, 2010; Hellström, 2007)

Malaysia, as a part of developing countries grants the green awareness at their National level. The Prime Minister, YAB, Dato Seri Najib Tun Abdul Razak introduced National Green Technology Policy in 2009. Out of four areas; energy, transport, building and manufacturing as a bridge to sustainability, manufacturing initiatives are hotly debated in literature since this sector is predominant for nations and social development. The automotive industries have significant contribution in Malaysian employment (more than 550,000 employees before and after market) and economic growth (3\%-4\% GDP per year) via manufacturing and marketing activities (Nurulizwa, Yahya, \& Samer, 2013; Samer, Majid, Rashid, \& Fasasi, 2012). This industries steadily growth since 1985 in technology transfer and product development while highly protected by the government because the industries encompass increasing number of company (up to 570 manufacturer and 35,000 aftermarket business) and build up from numerous components and suppliers in different industries such as metal, plastic, rubber, Electric \& Electronics and others. Ironically, in the recent years, automakers have faced a tremendous challenge since growing attention on sustainability development. Even though automotive industries relate on economic sustainability, however the impact on environmental and society are vice verse.

The automotives industry acknowledged as the main contributor for the $20 \%$ of $\mathrm{CO} 2$ emission (Machiba, 2009) and other source of air pollution such as particulates, sulphur dioxide, nitrogen dioxide, carbon monoxide and hydrocarbons mainly in urban areas (Nunes \& Bennett, 2006). On top of that, the auto industry related on the increasing number of waste by 25,000 tons/day, exploitation of natural resources along the product life cycle (PLC) and indirectly effects to social life; noise pollution, losses from accident and traffic congestion (Ariffin, 2012). Therefore, the current trends for the competitive advantage in global automotive industries rest on effective and efficient implementation of green manufacturing throughout introduction of cleaner technology, improves fuel efficiency, and developing green vehicles as the demand of green market increase globally mainly in Europe and United States (Kari \& Rajah, 2008).

The increasing of attention and global competition in a sustainability development has forcing the local automakers and suppliers to shift their paradigm in green production strategy and activities. The pressure to eco innovate relies on worsen of air quality, response on Global trends of producing hybrid and electric vehicles originated from Japanese, Chinese, and Indian countries (MAI, 2013; Pujari, Wright, \& Peattie, 2003) and compete with the traditional competitor which are Thailand and Indonesia (Yahya \& Nurulizwa, 2012). Therefore, the priority in New Automotive Policy (NAP) released on 20th January 2014 emphasizes on the sustainability implementation in producing auto product; car and motorcycles driven by the alternatives energy resources and emphasizing of green automotive life cycle through 3R concept (Reuse, Reduce, Remanufacturer) (MAI, 2013). The new trends of sustainability development resulted on growing research attention of how to manage manufacturing sustainability and successfully develop product based green innovation practices.

Sustainability research in automotive industry is central for the manufacturing management in exploring its drivers and barriers (Amrina \& Yusof, 2012), lean manufacturing implementation (Azlina, Salleh, Kasolang, \& Jaffar, 2011), performance indication (E.Amrina \& Yusof, 2011) and green practices (Conding, Mohd Zubir, Hashim, Sri Lanang, \& Habidin, 2012). In contrast, literature found that, in the new product development areas is limited on the eco design implementation (Gonzales, Sakundarini, Ariffin, \& Taha, 2010) (Taha, Sakundarini, Ariffin, Ghazila, \& Gonzales, 2010) and increasing research demand on how companies successfully managed 
eco product innovation development and its implementation (Eltayeb, 2009) while most of the companies in Malaysia are lacking on green information and not clear on capabilities needed to involve and performing green product development. In respect to the government regulations and market pull factors, for greener the product and value chain, a fruitful research needed as a platform for the companies to understand the effective way on managing eco product in two directions incremental or radical innovation. Incremental green practice is highly performed in end of pipe technology and Eco efficiency where 704 companies approved under Environmental Management System (653 companies) and Energy Management System (6 companies) respectively from SIRIM database. Yet, radical eco innovation practices is a new approach in manufacturing practices that reflect on new way of management and little companies invest in high technology by 314 green products registered under Green tech record and 57 products meet the requirements under eco label scheme in SIRIM certification since 2010. Therefore, there is an urgent call by both academicians and industries to explore the paramount management practices on how companies incorporate environmental requirements during developing a product either in incremental or radical approach. This research is significant as many manufacturing industry in Malaysia are still struggling to improve their product performance in the global competition. By introducing eco product innovation will increase the rank of Malaysian product nationally and globally.

\section{Acknowledgements}

This research is founded by UTeM short term grant under the following project S01151 PJP/2013/FPTT (4D).

\section{References}

Amrina, E., \& Yusof, S. mohd. (2012). Drivers and Barriers to Sustainable Manufacturing Initiatives in Malaysian Automotive Companies. In Proceedings of the Asia Pacific Industrial engineering and management systems conference 2012 (pp. 629-634).

Angelo, F. D., Jabbour, C. J. C., \& Galina, S. V. (2012). Environmental innovation: In search of a meaning. World Journal of Entrepreneurship, Management and Sustainable Development, 8(2/3), 113-121. http://dx.doi.org/10.1108/20425961211247734

Ariffin, N. (2012). Revisiting Malaysia's technology and R \& D-related policy studies and findings from 1990-2012 - review of effectiveness towards the technological capabilities of companies and industrial development. In International Symposium on Accelerating Innovation in Developing Countries.

Arundel, A., \& Kemp, R. (2009). Measuring eco innovation (pp. 1-40). Netherlands.

Azlina, N., Salleh, M., Kasolang, S., \& Jaffar, A. (2011). Lean TQM Automotive Factory Model System, (7), 535-541.

Bogliacino, F., Perani, G., Pianta, M., \& Supino, S. (2012). Innovation and Development: The Evidence From Innovation Surveys. Latin American Business Review, 13(3), 219-261. http://dx.doi.org/10.1080/ 10978526.2012.730023

Borin, N., \& Lindsey-mullikin, J. (2010). An analysis of consumer reactions to green strategies.

Brezet, J. (1997). Dynamics in ecodesign practice (pp. 21-41).

Carrillo-Hermosilla, J., del Río, P., \& Könnölä, T. (2010). Diversity of eco-innovations: Reflections from selected case studies. Journal of Cleaner Production, 18(10-11), 1073-1083. Retrieved from http://linkinghub.elsevier.com/retrieve/pii/S0959652610000612

Chen, Y. -S., Lai, S. -B., \& Wen, C. -T. (2006). The Influence of Green Innovation Performance on Corporate Advantage in Taiwan. Journal of Business Ethics, 67(4), 331-339. http://dx.doi.org/10.1007/s10551-006-9025-5

Conding, J., Mohd Zubir, A. F., Hashim, S., Sri Lanang, N. A., \& Fadly Habidin, N. (2012). The Investigation of Green Practices, Green Innovation and Green Performance in Malaysian Automotive Industry. Environmental Management and Sustainable Development, 2(1), 1-13.

Cooper, R. G., \& Edgett, S. J. (2006). Stage-Gate ${ }^{\circledR}$ and the Critical Success Factors for New Product Development. BPTrends, July 2006, 1-6.

Dangelico, R. M., \& Pujari, D. (2010). Mainstreaming Green Product Innovation: Why and How Companies Integrate Environmental Sustainability. Journal of Business Ethics, 95(3), 471-486. http://dx.doi.org/10.1007/s10551-010-0434-0

Driessen, P. H., Hillebrand, B., Kok, A. W., \& Verhallen, M. M. (2013). Green New Product Development: The pivotal role of product grenness. IEEE Transactions on Engineering Management, 60(2), 315-326. 
http://dx.doi.org/10.1109/TEM.2013.2246792

Dyllick, T., \& Hockerts, K. (2002). Beyond the Business Case for Corporate. Business Strategy and the Environment, 11, 130-141. http://dx.doi.org/10.1002/bse.323

Amrina, E., \& Yusof, S. M. (2011). Key Performance Indicators for Sustainable Manufacturing Evaluation in Automotive Companies. In Proceedings of the 2011 IEEE (pp. 1093-1097).

Ehrenfeld, J. (2001). Designing “Sustainable ” Product / Service Systems. In Ecodesign 2001 (pp. 1-12).

Eltayeb, T. K. (2009). Going Green Through Green Supply Chain Initiatives Towards Environmental Sustainability. Operations and Supply Chain Management, 2(2), 93-110.

Fussler, C., \& James, P. (1996). Driving eco innovation: A breakthrough disciplines for innovation and sustainability. London: Pitman.

Gonzales, J., Sakundarini, N., Ariffin, R., \& Taha, Z. (2010). Integrated Eco-Design Tool for Malaysian Automobile Industry. Journal of Advance Computational Intelligence and Intelligent Informatics, 14(1), 46-47.

Halila, F. (2007). The adoption and diffusion of environmental innovations.

Halila, F., \& Rundquist, J. (2011). The development and market success of eco-innovations: A comparative study of eco-innovations and "other" innovations in Sweden. European Journal of Innovation Management, 14(3), 278-302. http://dx.doi.org/10.1108/14601061111148807

Halila, \& Horte. (2006). Innovations that combine enviromental and business aspects. International Journal and Sustainable Development, 1(4). http://dx.doi.org/10.1504/IJISD.2006.013736

Hart, S. L. (1995). A Natural-Resource-Based View of the Firm. The Academy of Management Review, 20(4), 986.

Hart, S. L., Ahuja, G., \& Arbor, A. (1996). Does it pay to be green? an empirical examination of the relationship between emission reduction and firm performance. Business Strategy and the Environment, 5, 30-37. http://dx.doi.org/10.1002/(SICI)1099-0836(199603)5:1<30::AID-BSE38>3.0.CO;2-Q

Hayes, R., Pisano, G., Upton, D., \& Wheelwright. (2005). Operations, strategy and technology: Pursuing the competitive edge (Hoboken). New Jersey: John Wiley \& Sons.

Hellström, T. (2007). Dimensions of Environmentally Sustainable Innovation: The Structure of Eco-Innovation Concepts, 159(1), 148-159.

Kari, F., \& Rajah, R. (2008). Automobiles emsiions and the environment (pp. 1-346). Canada.

Kemp, R., \& Pearson, P. (2008). Final Report MEI Project about measuring eco innovation.

Kemp, R., \& Person, P. (2007). Final report MEI project about measuring eco- innovation.

Kijek, T., \& Kasztelan, A. (2013). Eco-innovation as a Factor of Sustainable Development. Problems of Sustainable Development, 8(2), 103-112.

Machiba, T. (2009). Framing eco innovation: the concept and the evolution of sustainable manufacturing (p. 22). OECD Publishing. Retrieved from http://www.oecdilibrary.org/oecd/content/book/9789264077225-en

MAI. (2013). Green mobility \& sustainability.

Manufacturing, S. (2009). Eco-innovation: Framework, Practices and Measurement. Paris.

Mei, O. J., Ling, K. C., \& Piew, T. H. (2012). The Antecedents of Green Purchase Intention among Malaysian Consumers, 8(13), 248-263.

Nunes, B., \& Bennett, D. (2006). Case Studies Green Innovation Management in the Automotive Industry Case Studies.

Nurulizwa, Y. S., \& Samer, S. (2013). Managing business dynamic and Changes. In Mc Graw Hill Publication (pp. 77-91). Selangor.

OECD. (2005). Oslo Manual: Guidelines for collecting and interpreting innovation data.

OECD. (2009). Sustainable Manufacturing and Eco-Innovation.

OECD. (2012). The future of Eco-innovation: The Role of Business Models in Green Transformation OECD Background Paper (pp. 1-27). 
Ottman, J., Stafford, E., \& Hartman, C. (2006). Green marketing myopia. Environment, 48(5), 22-36. http://dx.doi.org/10.3200/ENVT.48.5.22-36

Porter, M. (1991). Towards a dynamic theory of strategy. Stategic Management Journal, 12(S2), 95-117. http://dx.doi.org/10.1002/smj.4250121008

Porter, M., \& Linde, V. der. (1995). Green and competitive: Ending the stalemate.

Pujari, D. (2006). Eco-innovation and new product development: Understanding the influences on market performance. Technovation, 26(1), 76-85. http://dx.doi.org/10.1016/j.technovation.2004.07.006

Pujari, D., Peattie, K., \& Wright, G. (2004). Organizational antecedents of environmental responsiveness in industrial new product development. Industrial Marketing Management, 33(5), 381-391. http://dx.doi.org/10.1016/j.indmarman.2003.09.001

Pujari, D., Wright, G., \& Peattie, K. (2003). Green and competitive. Journal of Business Research, 56(8), 657-671. http://dx.doi.org/10.1016/S0148-2963(01)00310-1

Rennings, K. (2000). Redefining innovation - eco-innovation research and the contribution from ecological economics. Ecological Economics, 32(2), 319-332. http://dx.doi.org/10.1016/S0921-8009(99)00112-3

Rennings, K., \& Rammer, C. (2010). The Impact of Regulation-driven Environmental Innovation on Innovation Success and Firm Performance. Centre of European Economic Reserach (ZEW), 065(10).

Revilla Diez, J., \& Kiese, M. (2006). Scaling Innovation in South East Asia: Empirical Evidence from Singapore, Penang (Malaysia) and Bangkok. Regional Studies, 40(9), 1005-1023. http://dx.doi.org/10.1080/ 00343400600928277

Rogers E. M. (2003). Diffusion of innovation (5th ed.). New York: Free Press.

Russo, M. V., \& Fouts, P. A. (1997). A Resource-Based Perspective on Corporate Environmental Performance and Profitability. Academy of Management Journal, 40(3), 534-559. http://dx.doi.org/10.2307/257052

Samer, S. A. A., Majid, Z., Rashid, N., \& Fasasi, F. (2012). Inter-Firm Knowledge Transfer to the Capability of Local Parts Firms in the Malaysian Automobile Industry. European Journal of Business and Management, 4(18), 156-163.

Schiederig, T., Tietze, F., \& Herstatt, C. (2012). Green innovation in technology and innovation management - an exploratory literature review. R\&D Management, 42(2), 180-192. http://dx.doi.org/10.1111/j.1467-9310. 2011.00672.x

Sezen, B., \& Çankaya, S. Y. (2013). Effects of Green Manufacturing and Eco-innovation on Sustainability Performance. In Procedia - Social and Behavioral Sciences (Vol. 99, pp. 154-163). Elsevier B.V. http://dx.doi.org/10.1016/j.sbspro.2013.10.481

Sharma, V., Sonwalkar, J., \& Maohr, K. (2013). Consumer purchase behaviour for green product. Nepalese Academy of Managementjga, 1(1), 95-110.

Smith, B. (2008). Towards Radical Eco-Innovation: Fabric Care at Electrolux. Lund University.

Soliman, F. (2013). Does Innovation Drive Sustainable Competitive Advantages?, 9(1), 130-143.

Taha, Z., Sakundarini, N., Ariffin, R., Ghazila, R., \& Gonzales, J. (2010). Eco Design in Malaysian Industries: Challenges and Opportunities, 6(12), 2143-2150.

Tsen, C., Phang, G., Hasan, H., \& Buncha, M. R. (2006). Going Green : A Study of Consumers' Willingness to Pay for Green Products in.

WCED. (1987). The world commision on environment and development: Our common future. New York.

Yahya, S., \& Nurulizwa. (2012). Strategic Application of Advance Product Quality Planning in the Automotive Industry. In Malaysian Technical Universities Conference on Engineering and technology (MUCET) 2012 (pp. 657-666).

\section{Copyrights}

Copyright for this article is retained by the author(s), with first publication rights granted to the journal.

This is an open-access article distributed under the terms and conditions of the Creative Commons Attribution license (http://creativecommons.org/licenses/by/3.0/). 